\title{
Pengaruh Antrian Dan Kualitas Pelayanan Terhadap Kepuasan Pelanggan Biznet Home Di Branch Kelapa Gading
}

\author{
Vicky Desna Adi Lelono, Resista Vikaliana \\ Program Studi, Manajemen Logistik, Fakultas Ilmu Sosial dan Manajemen, Institut \\ Ilmu Sosial dan Manajemen STIAMI ${ }^{1,2}$ \\ *Email korespondensi: dosenresistaok@gmail.com
}

\begin{abstract}
The purpose of this research is to determine the effect of queue, service quality on customer satisfaction of Biznet Home in Kelapa Gading Branch partially and simultaneously. The population in this research is the customers of Biznet Home in the Jakarta Utara region. Total sample amount of this research is 32 respondents, which for the sampling here by using the Purposive Sampling technique. Data collected by using survey method with questionnaire instrument. For the data analysis method used by the researcher, is double regression analysis, $t$ test (partial) and $F$ test (simultaneous). From the result of this research shows that: (1) The effect of Queue positively affects the customer satisfaction, with tcount $3.912>$ from ttable or 3.912>2.045 then H1 is accepted. (2) The Service Quality significantly affects the customer satisfaction, tcount $6.653>$ from the ttable or $6.653>2.045$ then $\mathrm{H} 2$ is accepted. From the result of those hypothesis test then the decision taken is simultaneously all of the independent variable has positive and significant effects on customer satisfaction..
\end{abstract}

Keywords: Queue, Service Quality, Customer Satisfaction.

\section{PENDAHULUAN}

Dalam kehidupan sehari hari, antrian/ queuing atau waiting line sangat sering dijumpai. Dalam hal ini antrian terjadi pada saat ada pihak yang harus menunggu untuk mendapatkan pelayanan, sebagai contoh antrian pelayanan di loket pembelian tiket commuter line (Vikaliana, 2017).

Penelitian terdahulu tentang kualitas layanan memiliki pengaruh yang positif dan signifikan terhadap kepuasan konsumen studi kasus di restoran Happy Garden (Widjoyo et al., 2014). Hal ini berarti jika kualitas layanan ditingkatkan maka kepuasan konsumen restoran juga akan meningkat (Tjiptono, 2005). Penelitian lain membuktikan bahwa Teori Antrian berpengaruh terhadap tingkat kepuasan pelanggan (Lucyantoro \& Rachmansyah, 2017)

Konsumen dapat menilai pelayanan sistem antrian suatu perusahaan jasa layanan internet apakah berjalan dengan baik sesuai sesuai standarisasi perusahaan 
atau tidak. Seperti pada penyedia jasa layanan internet Biznet Branch Kelapa Gading. Antrian di Biznet ini terbentuk bila banyaknya pelanggan yang akan dilayani, melebihi kapasitas yang tersedia. Selain itu timeline antrian yang diterapkan juga digunakan untuk mengidentifikasi permasalahan yang terjadi dan sebagai pedoman dalam menentukan kebijakan bagi perusahaan, dan biasanya masalah ini terjadi pada saat proses antrian penjadwalan instalasi internet kesisi customer Biznet . Serta Lead Time lamanya penjadwalan untuk pengerjaan instalasi. Jadwal instalasi yang terlalu lama dan tidak sesuai SOP dari manajement yaitu estimasi 2 - 5 Hari setelah pembayaran sudah harus terpasang cukup sering lebih dari Maksimal 5 Hari baru bisa diselsaikan instalasinya .

Masalah yang dihadapi oleh pihak Biznet Branch Kelapa Gading tersebut harus ditemukan jalan keluarnya karena jika dilihat dari dampaknya akan membuat customer tersebut beralih tidak jadi berlangganan internet Biznet sehingga customer tersebut bisa membatalkan instalasi yang sudah dijadwalkan sehingga customer bisa refund, jika customer refund akan berimbas pada target sales yang semakin sulit tercapai .

Biznet didirikan pada tahun 2000. Meskipun relatif cukup lama dalam bisnis retail tersebut, tetapi penetrasi ke sisi pelanggannya paling baik. Hal ini ditempuh melewati terobosan Biznet membina layanan Metro Ethernet yaitu jaringan fiber optic di distrik Jakarta. Saat ini banyak sekali vendor penyedia layanan wi-fi contohnya ISP di Indonesia masih dikuasai sejumlah pemain utama, khususnya yang mempunyai jaringan yang luas. Beberapa pemain utama pada bisnis ISP ialah Telkom, Indosat Mega Media (IM2), Excelcomindo, First media , MNC Playmedia ,Broadband Multimedia, My Republik ,Oqygen dan lain-lain. Biznet saat ini menggunakan jaringan kabel Fiber Optic sebagai media transmisi internet ke pelanggan, sehingga bandwith yang bisa di alokasikan lebih besar dan stabil .

Biznet Home internet Merupakan layanan intrnet ultra cepat untuk rumah dan apartment dengan kecepatan koneksi hingga 150 Mbps baik untuk download maupun upload. Biznet melakukan expansi jaringan infrastruktur internet secara bertahap dibeberapa kota Besar di Indonesia cakupan areanya yang menjadi target meliputi perumahan, rukan, , apartment, gedung dan Mall .

Berikut Tabel 1 yang menunjukan daftar harga beserta paket yang ditawarkan oleh layanan Biznet Home . 
Tabel 1. Harga Paket Biznet Home

\begin{tabular}{|l|c|c|c|}
\hline Biznet Home & Harga Internet 1B & Harga Internet 2B & Harga Internet 3B \\
\hline 75 Mbps Ip Private & 325.000 & & \\
\hline 150 Mbps Ip Private & & 500.000 & \\
& & & 600.000 \\
\hline 150 Mbps Ip Publik & & & \\
\hline
\end{tabular}

Sumber: Internal Biznet Home, 2020

Jika dilihat dari Tabel 1 tersebut menunjukan bahwa untuk layanan Biznet Home tersebut memiliki bandwith yang cukup besar bagi segmentasi perumahan dan apartment yang mana diketahui saat ini layanan Internet yang cepat sangat dibutuhkan bagi pelanggan sehingga alokasi bandwith internet yang besar sangat mungkin memenuhi harapan pelanggan agar tidak lagi mengalami internet yang sering lambat .

Sebagai perbandingan harga layanan Biznet home dengan beberapa kompetitor yang selama ini menjadi head to head persaingan bisnis segmentasi retail dengan Biznet home, pada Tabel 2 berikut

Tabel 2. Perbandingan Harga Layanan ISP

\begin{tabular}{|c|c|c|c|}
\hline Penyedia internet & $\begin{array}{c}\text { Paket } \\
\text { Termurah }\end{array}$ & $\begin{array}{l}\text { Paket } \\
\text { Termahal }\end{array}$ & Bonus \\
\hline znet & $\begin{array}{l}75 \text { Mbps (Rp } \\
325 \text { ribu) }\end{array}$ & $\begin{array}{l}150 \text { Mbps } \\
\text { (Rp } 600 \text { ribu) }\end{array}$ & Video on demand \\
\hline & $\begin{array}{l}12 \text { Mbps (Rp } \\
323 \text { ribu) }\end{array}$ & $\begin{array}{l}200 \text { Mbps } \\
\text { ( Rp 2,9 juta) }\end{array}$ & $\begin{array}{l}\text { TV Kabel, video on } \\
\text { demand }\end{array}$ \\
\hline IndiHÔme & $\begin{array}{l}10 \mathrm{Mbps} \text { (Rp } \\
460 \text { ribu) }\end{array}$ & $\begin{array}{l}100 \text { Mbps } \\
\text { (Rp } 1,7 \text { juta) }\end{array}$ & $\begin{array}{l}\text { Telfon rumah, TV Kabel, } \\
\text { akses wifi.id }\end{array}$ \\
\hline Cplay & $\begin{array}{l}10 \mathrm{Mbps} \\
\text { (Rp230 ribu) }\end{array}$ & $\begin{array}{l}200 \text { Mbps } \\
\text { (Rp 2,9juta) }\end{array}$ & - \\
\hline
\end{tabular}

Sumber: id.techinasia.com, 2020

Tidak hanya dari segi harga yang menjadi persaingan Biznet dengan kompetitor kompetitor ISP tersebut namun dari sisi lain yaitu ketepatan jadwal instalasi, kualitas layanan dan after sales services pun menjadi tolok ukur kepuasan pelanggan. Di dalam antrian dikenal dengan disiplin antrian yaitu aturan di mana pelanggan dilayani atau disiplin pelayanan yang memuat urutan pelayanan yang menerima layanan (Kakiay, 2004). 
Di era digital yang sangat berkembang Saat ini, internet merupakan kebutuhan yang tidak dapat terlepaskan dari semua aspek kehidupan masyarakat modern yang memiliki mobilitas tinggi. Menurut data We Are Social, penduduk Indonesia rata-rata menghabiskan sembilan jam per hari untuk menggunakan internet. Fasilitas internet dapat membantu kehidupan masyarakat baik untuk berkomunikasi seperti untuk chatting, akses ke sosial media, berkirim surat melalui e-mail, berbelanja online, mencari informasi hingga berbisnis.

Penelitian ini bermaksud untuk menguji pengaruh penerapan Timeline antrian, Lead time penjadwalan instalasi serta kualitas layanan internet terhadap kepuasan pelanggan Biznet Home di Branch Kelapa Gading. Secara speksifik, tujuan penelitian ini adalah :

1. Untuk Menganalisis antrian (X1) berpengaruh secara signifikan terhadap Kepuasan pelanggan (Y) Biznet Home di Wilayah Kelapa Gading.

2. Untuk Menganalisis Kualitas pelayanan (X2) berpengaruh secara signifikan terhadap kepuasan pelanggan (Y) Biznet Home di Wilayah Kelapa Gading.

3. Untuk Menganalisis antrian (X1), dan Kualitas pelayanan (X2) Berpengaruh secara signifikan terhadap kepuasan pelanggan (Y) Biznet Home di Wilayah Kelapa Gading.

\section{KAJIAN PUSTAKA}

\section{Prinsip dari Sistem Antrian}

Di dalam teori antrian (queueing theori) Agner kraup erlang(1909) yang dikutip oleh Siswanto (2007:225) yang dapat membantu mengambil keputusan dalam merancang fasilitas pelayanan antrian untuk mengatasi permintaan pelayanan yang fluktuatif dan menjaga keseimbangan (biaya pelayanan dan waktu tunggu) dengan pendekatan sistem empat faktor (batasan sistem, input, proses ,output) dengan penerapan FIFOFirst In First Out setelah order masuk pada langkah yang harus dilakukan dalam melakukan aktivitas Sistem antrian pada customer yang akan dilakukan instalasi internet Biznethome, untuk mencapai sistem antrian yang efektif dan sesuai jadwal,. Langkah - langkah tersebut dapat dilihat pada Gambar 1 berikut ini:

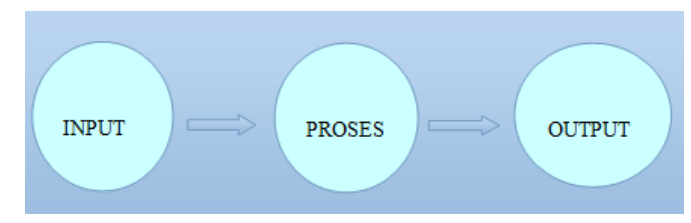

\section{Gambar 1 Sistem Parameter Teori Antrian}

\section{Karakteristik Sistem Antrian}

Terdapat tiga karakteristik dalam Teori antrian menurut Heizer dan Reinder (2011) yaitu kedatangan, Aturan antrian, dan dan pelayanan: 
a) Karakteristik Kedatangan

1. Ukuran atau populasi kedatangan

Tidak terbatas ketika terdapat materi atau orang-orang yang jumlahnya tidak terbatas dapat datang dan meminta pelayanan atau terbatas dimana hanya ada pengguna pelayanan yang potensial dengan jumlah terabatas.

2. Perilaku Kedatangan

Perilaku kedatangan mengg ambarkan perilaku pelanggan yang sabar menunggu dalam antrian hingga mereka dilayani dan tidak berpindah garis antrian atau menolak dan membelot dari antrian.

3. Pola Kedatangan

Pola kedatangan pelanggan untuk mengantri pada setiap unit waktu dapat diperkirakan oleh sebuah distribusi peluang yang disebut distribusi Poisson. Distribusi Poisson berarti kedatangan satu pelanggan dengan pelanggan lainnya tidak saling berhubungan dan jarak waktu antar kedatangan satu dengan yang lainnya hampir sama.

\section{Kualitas Pelayanan}

Kualitas pelayanan adalah faktor pendorong pada setiap perusahaan agar dapat tetap bersaing di pasar yang semakin ketat. Kualitas pelayanan juga penunjang dari suatu produk untuk dapat memuaskan para konsumenya, adapun pengertian Kualitas menurut para pakar sebagai berikut

Tjiptono (2009) menyatakan, service quality merupakan tingkat keunggulan yang diharapkan dan pengendalian atas tingkat keunggulan tersebut untuk memenuhi keinginan pelanggan. Konsumen yang menentukan berkualitas atau tidaknya suatu pelayanan jasa. Oleh karena itu, baik tidaknya kualitas jasa akan tergantung pada kemampuan penyedia jasa layanan internet dalam memenuhi harapan konsumennya secara konsisten.

\section{Kepuasan Pelanggan}

Kepuasan pelanggan dapat menjadi dasar menuju terwujudnya konsumen yang loyal atau setia. Philip Kotler (1997) mengemukakan bahwa kepuasan konsumen adalah tingkat perasaan seseorang setelah membandingkan kinerja atau hasil yang dirasakan dibandingkan dengan harapan (Pratiwi, 2010:36). Kepuasan didefinisikan sebagai persaaan senang atau kecewa seseorang dari membandingkan kinerja produk yang dirasakan dalam hubungan dan harapannya. 
Setelah mengetahui kerangka teori yang akan dibahas dibawah ini adalah gambaran terkait dari kerangka teori

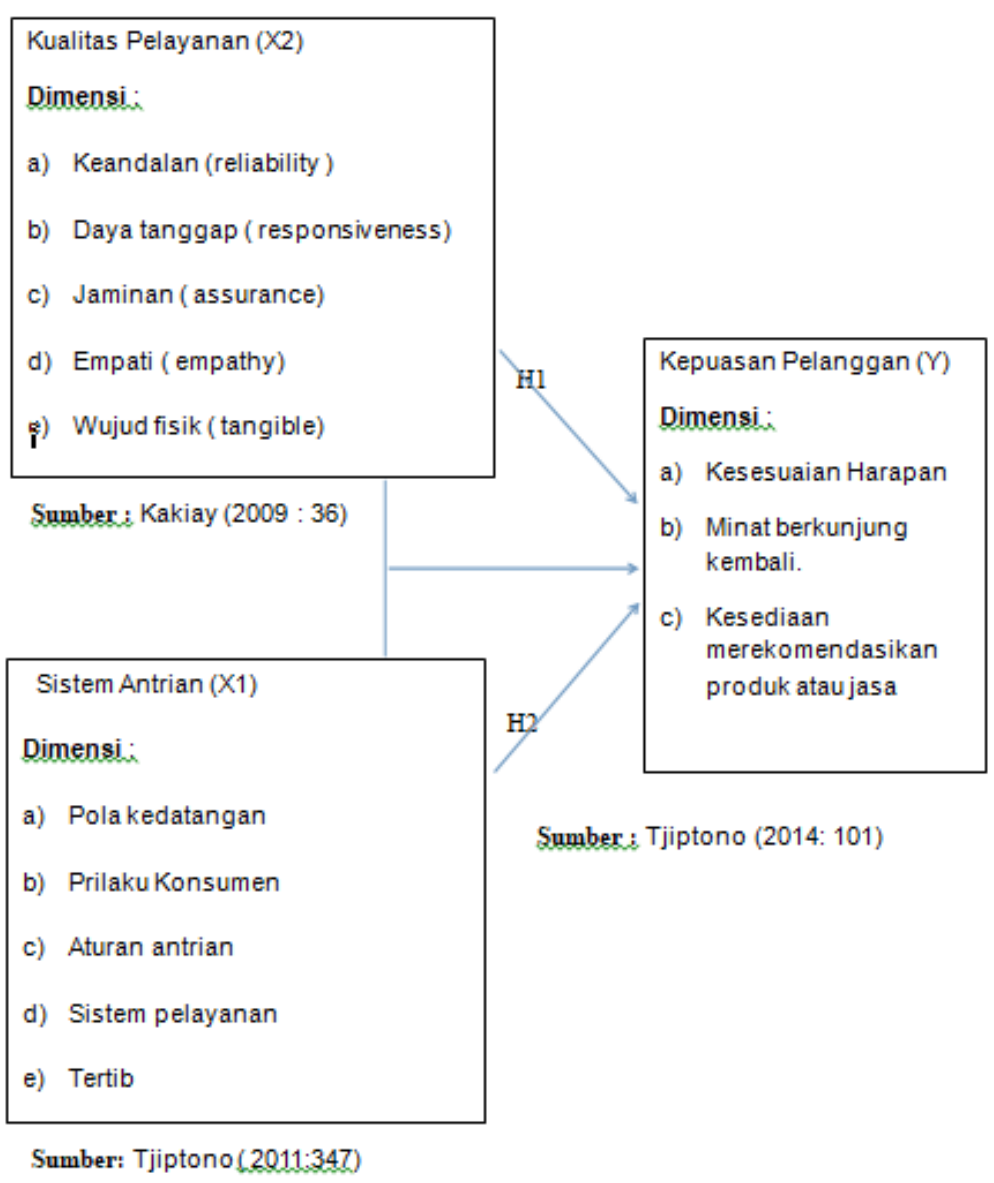

Gambar 2 Kerangka Teori Penelitian

\section{Hipotesis Penelitian}

Berdasarkan kerangka pemikiran teoritis di atas, maka hipotesis penelitian adalah berikut:

H1: Adanya pengaruh Positif dan signifikan antrian terhadap kepuasan pelanggan

H2: Adanya pengaruh Pengaruh positif dan signifikan kualitas pelayanan terhadap kepuasan

pelanggan

H3: Adanya pengaruh positif dan signifikan, Antrian dan kualitas pelayanan terhadap kepuasan pelanggan 


\section{METODE PENELITIAN}

Pendekatan penelitian ini adalah penelitian kuantitatif. Variabel penelitian terdiri atas dua macam, yaitu Variabel Terikat (dependent variabel) merupakan variabel yang dipengaruhi atau menjadi akibat, karena adanya variabel bebas. Dalam penelitian ini variabel terikatnya adalah Kepuasan Pelanggan. Kemudia, Variabel Bebas ( Independent variabel ) yang digunakan dalam penelitian ini adalah Antrian (X1) dan Kualitas pelayanan (X2).

Untuk mengetahui pengaruh pengaruh Antrian, Kualitas layanan, terhadap Kepuasan Pelanggan produk Biznet Home, menggunakan persamaan regresi linier berganda sebagai berikut:

\section{$Y=\alpha+\beta_{1} X_{1}+\beta_{2} X_{2}+\beta_{3} X_{3}+e$}

Keterangan :

Y: Variabel dependen

$\mathrm{X}$ : Variabel independen

a : Konstanta

$\mathrm{b}$ : Koefisien masing-masing variabel

e : Standar error

Populasi penelitian ini adalah pelanggan Biznet di Jakarta Utara, dengan sampel sejumlah 32 orang, yang diambil secara purposive sampling. Uji kualitas data yakni uji validitas dan realibitas dilakukan pada data hasil kuesioner. Kemudian uji asumsi klasik (uji normalitas, uji linieritas, uji heterokedastisitas dan uji multikolinieritas), digunakan sebagai syarat menguji model dengan analisis regresi linear berganda. Koefisien korelasi dan koefisien determinasi juga dilakukan untuk menguji kuat lemahnya pengaruh variabel-variabel bebas terhadap variabel terikat.

Uji hipotesis $\mathrm{t}$ untuk menguji pengaruh masing-masing variabel bebas. Kemudian dilakukan uji $\mathrm{F}$ untuk mengetahui apakah variabel bebas pada model mempunyai pengaruh secara bersama-sama terhadap variabel terikat. Pengolahan data penelitian ini dibantu dengan software SPSS (Vikaliana \& Irwansyah, 2019).

\section{HASIL PENELITIAN DAN PEMBAHASAN}

\section{Gambaran Umum Objek Penelitian}

Biznet didirikan pada tahun 2000, dan Biznet terus melakukan pengembangan dan perluasan jaringan sehingga sampai saat ini total jaringan Biznet Fiber Optic sejauh 
23.000 KM dengan total 450.000 Home pass yang tersebar di seluruh Indonesia didukung oleh lebih dari 2.600 karyawan terbaik. Bermula dari jumlah karyawan kurang dari 10 orang, Biznet telah berkembang secara signifikan dalam beberapa tahun. Biznet telah berhasil mengembangkan perusahaan dengan tidak hanya fokus pada penyediaan layanan Internet, tapi juga mengembangkan layanan Data Center, Cloud Computing dan Cable TV dikutip dari Website Biznet. www.biznetnetworks.com diakses pada tanggal 26 Juli 2020.

Pada awalnya PT. Supra Primatama Nusantara (Biznet Networks) adalah perusahaan B2B (Business To Business), namun perusahaan ini mendapatkan banyak perhatian, sehingga saat ini PT. Supra Primatama Nusantara (Biznet Networks) memperluaskan upaya nya menjadi perusahaan B2C (Business to Customer). Berkantor pusat di MidPlaza 2 8th Floor Jl. Jend Sudirman Kav 10-11, Jakarta.

\section{Gambaran Responder Penelitian}

Responden dalam penelitian ini adalah konsumen yang sudah berlangganan Biznet Home di Jakarta Utara. Melalui daftar pernyataan yang di ajukan oleh peneliti, dapat diketahui mengenai kondisi atau informasi tentang responden. Pernyataan yang diajukan terdiri dari data diri responden seperti jenis kelamin, usia, pekerjaan. Penggolongan yang dilakukan terhadap responden dalam penelitan ini bertujuan untuk mengetahui secara jelas mengenai gambaran responden sebagai objek penelitian. Hasil data yang telah disajikan dalam Tabel 3 berikut ini

Tabel 3. Gambaran Umum Responden

\begin{tabular}{|l|l|l|l|}
\hline \multicolumn{2}{|l|}{ Keterangan } & Jumlah & Persen \\
\hline \multirow{3}{*}{$\begin{array}{l}\text { Jenis } \\
\text { Kelamin }\end{array}$} & Laki-laki & 19 & $59,4 . \%$ \\
\cline { 2 - 4 } & Perempuan & 13 & $40,6 \%$ \\
\hline \multirow{4}{*}{ Total } & $<20$ tahun & 2 & $100 \%$ \\
\hline \multirow{4}{*}{ Usia } & $21-30$ tahun & 14 & $6,3 \%$ \\
\cline { 2 - 5 } & $31-40$ tahun & 8 & $43,8 \%$ \\
\cline { 2 - 5 } & $>40$ tahun & 8 & $25 \%$ \\
\hline Total & 32 & $100 \%$ \\
\hline
\end{tabular}

Sumber : Data diolah, 2020.

Berdasarkan Tabel 3 dapat dilihat bahwa responden penelitian sebanyak 32 responden. Responden berdasarkan jenis kelamin didominasi oleh laki-laki, hal ini 
dapat dilihat bahwa hasil presentasi paling tinggi berada pada bagian jenis kelamin laki-laki sebesar 59,4\%. Responden berdasarkan usia di dominasi pada umur 21 - 30 tahun, hal ini dapat di lihat bahwa hasil persentase paling tinggi berada pada bagian usia 21-30 tahun yaitu sebesar 43,8\%.

\section{HASIL PENELITIAN}

\section{Analisis Regresi Linear Berganda}

Menurut Ghozali (2006) mendefinisikan analisis regresi sebagai studi mengenai ketergantungan variabel dependen (terikat) dengan satu atau lebih variabel independen (bebas). Dalam penelitian ini, analisis regresi linear berganda ditujukan untuk mengetahui sejauh mana pengaruh variabel independen yaitu antrian, kualitas pelayanan, terhadap variabel dependen yaitu, kepuasan pelanggan

Tabel 4 Uji Regresi Linear Berganda

\begin{tabular}{|c|c|c|c|c|c|c|}
\hline \multicolumn{7}{|c|}{ Coefficients $^{a}$} \\
\hline & \multirow{2}{*}{ Model } & \multicolumn{2}{|c|}{$\begin{array}{c}\text { Unstandardized } \\
\text { Coefficients }\end{array}$} & \multirow{2}{*}{$\begin{array}{c}\begin{array}{c}\text { Standardiz } \\
\text { ed }\end{array} \\
\text { Coefficient } \\
\text { s }\end{array}$} & \multirow{2}{*}{$t$} & \multirow{2}{*}{ Sig. } \\
\hline & & B & $\begin{array}{l}\text { Std. } \\
\text { Error }\end{array}$ & & & \\
\hline \multirow{4}{*}{1} & (Constant) & 4.229 & 3.390 & & $\begin{array}{c}1.24 \\
8\end{array}$ & .22 \\
\hline & & & & & 3.91 & .00 \\
\hline & Antrian & .739 & .189 & .581 & 2 & 0 \\
\hline & $\begin{array}{l}\text { Kualitas } \\
\text { Pelayanan }\end{array}$ & .898 & .135 & .772 & $\begin{array}{c}6.65 \\
3\end{array}$ & $\begin{array}{c}.00 \\
0\end{array}$ \\
\hline
\end{tabular}

Sumber : Pengolahan Data Menggunakan SPSS 23, 2020

Berdasarkan data pada Tabel 4 di atas, maka dapat disimpulkan bahwa masingmasing variabel berpengaruh signifikan. Untuk uji signifikasi antrian sebesar $0.000<$ 0.05 atau hasil uji t dengan thitung $3.912>$ dari ttabel sebesar 2.045, dan untuk uji signifikasi Kualitas Pelayanan sebesar $0.000<0.05$ atau hasil dari uji t dengan thitung $6.653<$ dari ttabel sebesar 2.045 . berikut:

Berdasarkan hasil penelitian, persamaan regresi linier berganda adalah sebagai

$$
\mathrm{Y}=4.229+0.739 \mathrm{X} 1+0.898 \mathrm{X} 2+\mathrm{e}
$$

Rumus tersebut menunjukkan hubungan yang positif semua Variabel $X$ terhadap Variabel Y. 


\section{Analisis Koefisien Korelasi dan Koefisien Determinasi}

Tabel 5 Koefisien Korelasi dan Koefisien Determinasi

\begin{tabular}{|l|l|l|l|l|}
\hline \multicolumn{2}{|l|}{ Model Summary } \\
\hline Model & $\mathrm{R}$ & R Square & $\begin{array}{l}\text { Adjusted } \\
\text { Square }\end{array}$ & $\begin{array}{l}\text { Std. Error of the } \\
\text { Estimate }\end{array}$ \\
\hline 1 & $.788^{\mathrm{a}}$ & .621 & .595 & 2.83227 \\
\hline
\end{tabular}

Sumber : Pengolahan Data Menggunakan SPSS 23, 2020

Berdasarkan hasil penelitian, terlihat pada Tabel 5 di atas, koefisien korelasi pada penelitian ini sebesar 0.788 yang artinya hubungan antara variabel independen dengan dependen dalam penelitian tersebut dapat dikatakan mempunyai hubungan yang kuat. Pada Tabel 5 diketahui nilai Koefisien Determinasi (Adjusted $R$ square) sebesar 0.595 atau 59.5\%. Hal ini menunjukkan bahwa Antrian dan Kualitas Pelayanan memiliki pengaruh terhadap Kepuasan Pelanggan sebesar 59.5\% sedangkan sisa nya $40.5 \%$ dipengaruhi variabel lain di luar variabel pada model atau persamaan pada penelitian ini.

\section{Pengujian Hipotesis}

Uji t dilakukan untuk mengetahu signifikan variabel bebas terikat secara parsial.

Tabel 6 Uji Hipotesis t Variabel Antrian

\begin{tabular}{|l|l|r|r|r|r|c|}
\hline \multicolumn{2}{|c|}{ Model } & \multicolumn{2}{|c|}{$\begin{array}{c}\text { Unstandardized } \\
\text { Coefficients }\end{array}$} & $\begin{array}{c}\text { Standardized } \\
\text { Coefficients }\end{array}$ & \multirow{2}{*}{$\mathrm{t}$} & \multirow{2}{*}{ Sig. } \\
\cline { 2 - 6 } & $\mathrm{B}$ & Std. Error & Beta & & \\
\hline \multirow{3}{*}{1} & (Constant) & 13.199 & 3.626 & & 3.640 & .001 \\
\cline { 2 - 7 } & Antrian & .739 & .189 & .581 & 3.912 & .000 \\
\hline
\end{tabular}

Sumber : Pengolahan Data Menggunakan SPSS 23, 2020

Berdasarkan Tabel 6 di atas, Variabel Antrian dengan thitung $3.912>$ dari ttabel atau 3.912 > 2.045, maka H0 ditolak atau H1 diterma. Artinya, Antrian memiliki pengaruh terhadap Kepuasan Pelanggan.

\section{Uji Hipotesis $F$}

Hasil pengujian ANOVA dengan menggunakan uji F menunjukkan nilai Fhitung sebesar 23.785 dengan signifikasi 0,000, dengan mencari Ftabel. Ftabel dapat dilihat pada tabel statistik (lihat lampiran) pada tingkat signifikasi 0.05 dan df2 
(jumlah variabel -1) = 0, dan df2 (n-k-1) atau 32-2-1= 29 (n adalah jumlah data, $\mathrm{k}$ adalah jumlah variabel independen). Hasil perolehan uji Ftabel sebesar 2.93 dengan kondisi Fhitung 23.785 > 2.93 dari Ftabel dan nilai signifikasi lebih kecil dari alpha (0.05). Dari hasil uji hipotesis tersebut maka secara simultan, Antrian dan Kualitas Pelayanan mempunyai pengaruh yang signifikan terhadap Kepuasan Pelanggan.

\section{PEMBAHASAN}

Hasil uji menunjukan bahwa Antrian dan Kualitas Pelayanan memiliki pengaruh yang signifikan terhadap Kepuasan Pelanggan, baik secara parsial maupun secara simultan. Hal ini sejalan dengan Teori Thomas J. Kakiay. (Kakiay, 2006), serta sejalan dengan penelitian yang terdahulu (Lucyantoro \& Rachmansyah, 2017; Widjoyo et al., 2014).

Hasil pengolahan data diketahui nilai Koefisien Korelasi menunjukkan korelasi yang kuat, serta menunjukkan bahwa antrian dan kualitas pelayanan memiliki pengaruh terhadap kepuasan pelanggan sebesar 59.5\% sedangkan sisa nya $40.5 \%$ dipengaruhi variabel lain yang tidak diteliti oleh penulis. Hasil ini tidak bertentangan dengan penelitian yang telah dilakukan sebelumnya, bahwa baik Teori Antrian maupun Kualitas Pelayanan berpengaruh secara parsial dan simultan terhadap Kepuasan Pelanggan (Lucyantoro \& Rachmansyah, 2017; Widjoyo et al., 2014).

\section{SIMPULAN DAN SARAN}

\section{Kesimpulan}

Berdasarkan hasil penelitian diperoleh, maka penulis mengambil kesimpulan sebagai berikut :

1. Diperoleh persamaan regresi linier berganda, yaitu $Y=4.229+0.739 \mathrm{X} 1+0.898 \times 2$ $+\mathrm{e}$

yang menunjukkan bahwa Variabel Antrian dan Kualitas Pelayanan berpengaruh positif dan signifikan terhadap Variabel Kepuasan Pelanggan.

2. Uji Hipotesis menunjukkan bahwa Variabel Antrian dan Kualitas Pelayanan memiliki pengaruh yang signifikan terhadap Kepuasan Pelanggan, baik secara parsial maupun secara simultan.

3. Berdasarkan hasil penelitian diperoleh nilai Koefisien Korelasi menunjukkan korelasi yang kuat, serta menunjukkan bahwa antrian dan kualitas pelayanan memiliki pengaruh terhadap kepuasan pelanggan sebesar $59.5 \%$ sedangkan sisa nya $40.5 \%$ dipengaruhi variabel lain yang tidak diteliti oleh penulis

\section{Saran}

Berdasarkan hasil penelitian yang sudah diperoleh maka peneliti menyarankan bahwa dalam menerapkan Sistem Antrian Instalasi dengan Metode FIFO harus diimbangi dengan Man Power pada Operasional yang memadai, sehingga 
mengurangi waktu tunggu instalasi yang panjang. Hal ini akan berdampak pada kepuasan pelanggan pada kualitas pelayanan dari Biznet. Diharapkan pelanggan yang merasa puas tersebut akan merekomendasikan ke kerabat dan koleganya.

Perusahaan Biznet yang saat ini berkembang dan tumbuh semakin pesat di beberapa kota kota besar di Indonesia. Berdasarkan hasil penelitian, kualitas pelayanan Internet berpengaruh pada kepuasan pelanggan Biznet. Sehingga, disarankan melakukan perbaikan terhadap kegiatan operasional instalas, khususnya saat permintaan tinggi. Manajemen diharapkan dapat segera menemukan cara supaya antrian jadwal instalasi tidak semakin lama, sehingga Biznet akan mendapatkan nilai lebih dari pelanggan.

\section{DAFTAR PUSTAKA}

Ghozali, Imam. (2006). Aplikasi Analisis Multivariate dengan Program SPSS (Edisi Ke 4). Semarang:Badan Penerbit Universitas Diponegoro

Gross, Donald. (2008). Fundamental of Queueing theory. New Jersey: Wiley.

Heizer,J. Dan Reinder, B. (2005). Manajemen operasi. Salemba Empat : Jakarta.

Kakiay, Thomas J.2006. Pengantar sistem simulasi. Yogyakarta : Penerbit Andi.

Siswanto. 2007. Operation research jilid II, jakarta, Erlangga.

Lucyantoro, B. I., \& Rachmansyah, M. R. (2017). PENERAPAN STRATEGI DIGITAL MARKETING , TEORI ANTRIAN TERHADAP TINGKAT KEPUASAN

PELANGGAN ( Studi Kasus di MyBCA Ciputra World Surabaya).

Tjiptono, F. (2005). Brand Strategy and Management.

https://scholar.google.co.id/scholar?hl=en\&as_sdt=0,5\&cluster=172788060327751 40103

Vikaliana, R. (2017). ANALYSIS OF COMMUTER LINE TICKET PURCHASE. 02(02), 35-44.

Vikaliana, R., \& Irwansyah. (2019). Pengolahan Data dengan SPSS. CV AA RIZKY. https://ideas.repec.org/p/osf/thesis/zhym7.html

Widjoyo, S., Hatane, P., Brahmana, R. K. M. R., Pemasaran, J. M., Petra, U. K., \& Siwalankerto, J. (2014). Pengaruh kualitas layanan dan kualitas produk terhadap kepuasan pelanggan dan loyalitas konsumen restoran happy garden surabaya. 2(1), 1-9. 